\title{
WCZEŚNIEJSZA ZNAJOMOŚĆ MARKI SPONSORA JAKO DETERMINANTA OSIĄGANYCH PRZEZ NIEGO EFEKTÓW W OBSZARZE BRAND EQUITY
}

Firmy angażujące się w sponsoring, decydują się na tę formę promocji, oczekując w zamian konkretnych korzyści. Spektrum możliwych do osiągnięcia efektów wynikających z wejścia w alians sponsoringowy z danym podmiotem jest bardzo szerokie. Nie mniej pokaźna jest jednak liczba zmiennych, które pośrednio lub bezpośrednio wpływają na poziom osiąganych efektów. W pracy autor stara się określić, jaka jest relacja pomiędzy znajomością firmy wśród fanów sponsorowanego podmiotu, zanim ta została sponsorem, a osiąganymi przez tę firmę efektami w zakresie marketingowej wartości marki. Postawiono zatem pytanie, czy firmy dotychczas nieznane wśród osób, które są uczestnikami sponsorowanego wydarzenia, mogą liczyć na takie same efekty sponsoringowe we wspomnianym obszarze, co firmy znane. Marketingowa wartość marki i zmiany w jej obrębie będące rezultatem inwestycji sponsoringowej były analizowane przez pryzmat czterech wskaźników: świadomość marki, wizerunek marki, stosunek wobec marki oraz intencja zakupów produktów danej marki.

Dorobek w tym zakresie wciąż jest bardzo niewielki. Głównym wkładem niniejszego artykułu jest podsumowanie dotychczas dostępnej literatury przedmiotu, czyli zaprezentowanie w jednym miejscu wiedzy z poprzednich badań. W rezultacie ma się to przyczynić do lepszego zrozumienia omawianej relacji, a także pomóc w wyznaczaniu obszarów wymagających dalszych prac badawczych. Artykuł kończy się wskazówkami praktycznymi dla obecnych, jak również przyszłych sponsorów. Wiedza w tym obszarze jest istotna chociażby przy szacowaniu korzyści płynących z rozpoczęcia sponsorowania wybranego podmiotu.

Słowa kluczowe: sponsoring, efekty sponsora, wcześniejsza znajomość marki sponsora, marketingowa wartość marki, determinanty efektów sponsora

\section{WPROWADZENIE}

Sponsoring jest jednym $\mathrm{z}$ najszybciej rozwijających się narzędzi marketingu w ostatnich dekadach ${ }^{2}$. Zgodnie $\mathrm{z}$ raportami SRI ${ }^{3}$ oraz $\mathrm{IEG}^{4}$ na przestrzeni lat 1984-2014 globalne wydatki na tę formę promocji wzrosły z dwóch do ponad 55 miliardów dolarów. Olbrzymi wzrost zainteresowania sponsoringiem zauważalny jest również w Polsce, gdzie w latach 2001-2012 wartość rynku sponsoringowego tylko w zakresie sportu zwiększyła się o ponad $1300 \% 5$.

\footnotetext{
${ }^{1}$ Rafał Matczyński, doktorant, Katedra Marketingu Produktu, Uniwersytet Ekonomiczny w Poznaniu, al. Niepodległości 10, 61-875 Poznań, tel.: 6185694 52, e-mail: rafal.matczynski@ ue.poznan.pl

${ }^{2}$ T. Meenaghan, P. O'Sullivan, Metrics in Sponsorship Research - Is Credibility an Issue?, „Psychology and Marketing" 30/5 (2013), s. 409.

${ }^{3}$ SRI, World-Wide Sponsorship Market Values, Sponsorship Research International, London 2001.

${ }^{4}$ IEG, Sponsorship report, 2009; IEG, Sponsorship spending report, 2014; IEG, Sponsorship spending report, 2015.

${ }^{5}$ Sponsoring - podstawowy instrument marketingu sportowego, Deloitte i Krajowa Izba Sportu, Warszawa 2012, s. 12.
} 
Sponsorzy angażują się w działania sponsoringowe i przeznaczają na nie coraz większe kwoty pieniędzy, w zamian zaś mają nadzieję uzyskać różnorodne korzyści. Do owych profitów można zaliczyć między innymi wzrost sprzedaży, wzrost morale pracowników oraz polepszanie relacji $\mathrm{z}$ interesariuszami. Wśród najczęściej wymienianych znajdują się jednak te w obszarze wartości marki. Wspomniany konstrukt ma dwa podstawowe znaczenia: finansowe (brand value) oraz marketingowe (brand equity). Niniejsza praca skupia się tylko na tym drugim aspekcie. W literaturze jest dostępnych wiele rozmaitych koncepcji próbujących uchwycić naturę marketingowej wartości marki. Jedną z popularniejszych jest definicja autorstwa Aaker, zgodnie z którą „brand equity stanowi kombinację aktywów i pasywów związanych z marką (jej nazwą, symbolem), która powiększa lub pomniejsza wartość, jaką produkt lub usługa dostarcza przedsiębiorstwu i/lub klientom tego przedsiębiorstwa" ". Według wspomnianego autora, konstrukt ten obejmuje takie elementy jak: świadomość marki, postrzeganą jakość, skojarzenia $\mathrm{z}$ marką oraz lojalność wobec niej (rys. 1). Natomiast w badaniach nad wartością marki w sponsoringu najczęściej posługiwano się takimi miarami, jak wzrost poziomu świadomości marki, zmiana wizerunku marki, polepszenie stosunku wobec niej oraz przyrost intencji zakupu produktów sponsora ${ }^{7}$.

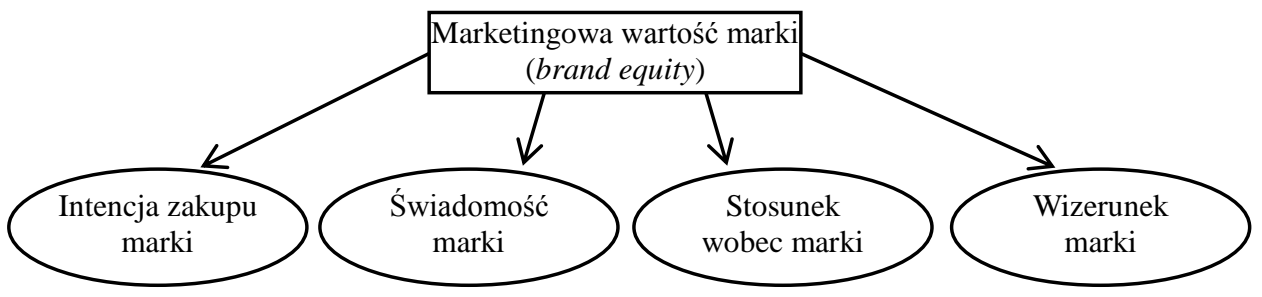

Rys. 1. Najczęściej wykorzystywane wskaźniki marketingowej wartości marki w badaniach prowadzonych w obszarze sponsoringu

Wspomniane efekty w obszarze brand equity, na jakie liczą firmy angażujace się w działalność sponsoringową, zależą od wielu okoliczności, czyli zmiennych niezależnych. Generalnie można je rozpatrywać w podziale na trzy grupy, a mianowicie: zmienne związane z podmiotem sponsorowanym, z podmiotem sponsorującym oraz z uczestnikiem wydarzenia sponsorowanego. W niniejszej pracy autor skupia się tylko na jednej determinancie związanej z uczestnikiem, a dokładnie - na znajomości firmy, zanim ta została sponsorem. Postawiono pytanie, czy dotychczas nieznane firmy uzyskują takie

${ }^{6}$ D.A. Aaker, Building strong brands: Capitalizing on the value of brand name, The Free Press, New York 1996, s. 7.

${ }^{7}$ T.B. Cornwell, I. Maignan, An international review of sponsorship research, „Journal of Advertising” 27/1 (1998), s. 1-21; B. Walliser, An international review of sponsorship research: An extension and update, „International journal of advertising” 2003/22, s. 5-40; K.P. Gwinner, J. Eaton, Building Brand Image Through Event Sponsorship: The Role of Image Transfer, „Journal of Advertising” 28/4 (1999), s. 47-57; K. Gwinner, S.R. Swanson, A model of fan identification: antecedents and sponsorship outcomes, „Journal of Services Marketing" 17/3 (2003), s. 275-294; R. Grohs, U. Wagner, S. Vsetecka, Assessing the Effectiveness of Sport Sponsorships - an Empirical Examination, „Schmalenbach Business Review” 56/2 (2004), s. 119-138; R. Speed, P. Thompson, Determinants of sport sponsorship response, „Journal of the Academy of Marketing Science" 28/2 (2000), s. 226-238. 
same efekty w czterech wspomnianych wskaźnikach wartości marki w wyniku zaangażowania się w sponsoring, co firmy znane, przy założeniu, że firmy te nie różnią się w innych aspektach (np. w wielkości pakietu sponsorskiego albo branży, w której działają)? Chodzi tu zatem o wskazanie firmy (znana versus nieznana wśród fanów sponsorowanego wydarzenia), która w wyniku rozpoczęcia sponsorowania może liczyć na większe zmiany w marketingowej wartości swojej marki. Każdy specjalista ds. marketingu, który wydaje pieniądze na sponsoring, liczy w rezultacie na pewne rezultaty podjętej decyzji. Stąd wiedza w omawianym obszarze jest bardzo istotna. Jeśli bowiem znajomość firmy wśród kibiców (zanim została sponsorem) jest silną determinantą efektów sponsora, sponsoring jako narzędzie promocji nie będzie przynosić takich samych korzyści firmom, które na wejściu różnią się poziomem znajomości wśród uczestników sponsorowanego wydarzenia.

\section{ZNAJOMOŚĆ MARKI (BRAND FAMILIARITY)}

Efektywność działań komunikacyjnych w marketingu w dużym stopniu zależy od konsumenckiej znajomości marki oraz jej wizerunku ${ }^{8}$. Znajomość marki definiowana jest jako poziom jej pośredniego lub bezpośredniego doświadczenia przez konsumenta, na przykład przez wcześniejsze użycie jej produktów lub oglądanie reklam z jej udziałem ${ }^{9}$. Jest to zatem poziom nagromadzonych do tej pory informacji o marce. Truizmem jest stwierdzenie, że pewna część uczestników sponsorowanego wydarzenia może już posiadać jakąś wiedzę na temat danej marki, jeszcze zanim ta zaangażuje się w sponsoring.

W literaturze wskazuje się, że to, w jakim stopniu osoba zna konkretną markę, istotnie wpływa na przebieg procesów przetwarzania nowych informacji $\mathrm{z}$ nią związanych, których źródłem może być na przykład uczestnictwo w sponsorowanym przez nią wydarzeniu $^{10}$. Znajomość marki odgrywać zatem może ważną rolę w osiąganiu efektów działań sponsoringowych ${ }^{11}$. Na różne rezultaty bowiem liczyć może sponsor w zależności od dotychczasowego poziomu znajomości jego marki wśród widzów sponsorowanego wydarzenia. Nie da się jednak jednoznacznie stwierdzić, że znana firma, która zaczyna inwestować w sponsorowanie, osiągnie większe korzyści $\mathrm{W}$ porównaniu $\mathrm{z}$ tymi zyskiwanymi przez firmę dotychczas słabo znaną. Poziom znajomości marki nie wpływa bowiem jednakowo na zmiany w obszarze wszystkich wymiarów marketingowej wartości marki. W tabeli 1 przedstawiono opisane do tej pory w literaturze badania, w których podjęto się próby określenia wpływu omawianej zmiennej na różne wymiary brand equity.

\footnotetext{
${ }^{8}$ K.L. Keller, Conceptualizing, Measuring and Managing Customer Based Brand Equity. „Journal of Marketing" 1993/57, s. 1-22.

9 J.W. Alba, J.W. Hutchinson, Dimensions of consumer expertise, ,Journal of Consumer Research” 13/4 (1987), s. 411.

${ }^{10} \mathrm{~T}$. Meenaghan, The role of sponsorship in the marketing communication mix, „International Journal of Advertising" 10/1 (1991), s. 35-47; M. Walraven, Sports Sponsorship Effectiveness. Investigating awareness, sponsor equity and efficiency, dysertacja doktorska, 2013

${ }^{11}$ F.A. Carrilat, E.G. Harris, B.A. Lafferty, Investigating sponsorships effectiveness: Do less familiar brands have an advantage over more familiar brands in single and multiple sponsorship arrangements?, „Journal of Brand Management" 13/1 (2005), s. 50-64.
} 
Tabela 1. Przegląd badań skupionych na wartości marki sponsora, w których jedną z analizowanych zmiennych jest wcześniejsza znajomość marki sponsora

\begin{tabular}{|c|c|c|c|c|}
\hline Autorzy & $\begin{array}{l}\text { Metoda i próba } \\
\text { badawcza }\end{array}$ & Kraj & $\begin{array}{l}\text { Badany efekt } w \\
\text { obszarze } \\
\text { wartości marki }\end{array}$ & $\begin{array}{l}\text { Jak zoperacjonalizowano } \\
\text { zmienną: wcześniejsza } \\
\text { znajomość marki? }\end{array}$ \\
\hline $\begin{array}{l}\text { Johar i } \\
\text { Pham (1999) }\end{array}$ & $\begin{array}{l}3 \text { eksperymenty: } \\
\mathrm{I}-\mathrm{n}=44 \\
\mathrm{II}-\mathrm{n}=65 \\
\mathrm{III}-\mathrm{n}=78\end{array}$ & $\begin{array}{l}\text { Stany } \\
\text { Zjedno- } \\
\text { czone }\end{array}$ & $\begin{array}{l}\text { Świadomość } \\
\text { sponsora }\end{array}$ & $\begin{array}{l}\text { W preteście badani } \\
\text { zakwalifikowali pewne marki } \\
\text { do znanych, inne do } \\
\text { nieznanych }\end{array}$ \\
\hline $\begin{array}{l}\text { Johar i } \\
\text { Pham (2001) }\end{array}$ & $\begin{array}{l}\text { Eksperyment, } \\
\text { czytanie wycinków } \\
\text { prasowych o } 12 \\
\text { wydarzeniach } \\
\text { sportowych, } \mathrm{n}=34\end{array}$ & $\begin{array}{l}\text { Stany } \\
\text { Zjedno- } \\
\text { czone }\end{array}$ & $\begin{array}{l}\text { Świadomość } \\
\text { sponsora }\end{array}$ & $\begin{array}{l}1 \text { - zakwalifikowanie marki } \\
\text { do znanej lub nieznanej } \\
\text { zależało od jej udziałów w } \\
\text { rynku } \\
2 \text { - badany oceniał stopień } \\
\text { znajomości z daną marką }\end{array}$ \\
\hline $\begin{array}{l}\text { Grohs, } \\
\text { Wagner i } \\
\text { Vsetecka } \\
(2004)\end{array}$ & $\begin{array}{l}\mathrm{N}=132 \\
\text { Badanie przed } \\
\text { Mistrzostwami } \\
\text { Świata } \mathrm{w} \\
\text { Narciarstwie } \\
\text { Alpejskim i po nich }\end{array}$ & Austria & $\begin{array}{l}\text { Świadomość } \\
\text { sponsora } \\
\text { Wizerunek marki } \\
\text { sponsora }\end{array}$ & $\begin{array}{l}\text { W I pomiarze zadano } \\
\text { pytanie: czy znane są Tobie } \\
\text { nazwy firm: } \\
\text { BMW, Milka, Telekom } \\
\text { Austria, Tag Heuer, } \\
\text { Memphis, Carlsberg }\end{array}$ \\
\hline $\begin{array}{l}\text { Carrillat, } \\
\text { Lafferty } \\
\text { Harris } \\
(2005)\end{array}$ & $\begin{array}{l}\mathrm{N}=172, \\
\text { eksperyment } \\
\text { (4 grupy), jeden } \\
\text { pomiar }\end{array}$ & $\begin{array}{l}\text { Stany } \\
\text { Zjedno- } \\
\text { czone }\end{array}$ & $\begin{array}{l}\text { Stosunek do } \\
\text { marki sponsora } \\
\text { Intencja zakupu } \\
\text { produktu } \\
\text { sponsora }\end{array}$ & $\begin{array}{l}\text { Oceniana znajomość marki, } \\
\text { doświadczenie z marką oraz } \\
\text { wiedza na jej temat } \\
\text { (7-stopniowa skala) }\end{array}$ \\
\hline $\begin{array}{l}\text { Wakefield, } \\
\text { Becker- } \\
\text { Olsen i } \\
\text { Cornwell } \\
(2006)\end{array}$ & $\begin{array}{l}\mathrm{N}=209, \\
\text { eksperyment }\end{array}$ & $\begin{array}{l}\text { Stany } \\
\text { Zjedno- } \\
\text { czone }\end{array}$ & $\begin{array}{l}\text { Świadomość } \\
\text { sponsora }\end{array}$ & $\begin{array}{l}\text { Zadano pytanie: } w \\
\text { porównaniu z firmami } \\
\text { konkurencyjnymi, jak duża } \\
\text { i popularna jest ta firma? (10- } \\
\text { stopniowa skala) }\end{array}$ \\
\hline $\begin{array}{l}\text { Hoek, } \\
\text { Gendall i } \\
\text { Wood } \\
(2006)\end{array}$ & $\begin{array}{l}\mathrm{N}=425 \text { osób w } \\
\text { centrum } \\
\text { handlowym, jeden } \\
\text { pomiar, badanie } \\
\text { podczas Olimpiady } \\
\text { w Grecji w } 2004 \mathrm{r} \text {. }\end{array}$ & $\begin{array}{l}\text { Nowa } \\
\text { Zelandia }\end{array}$ & $\begin{array}{l}\text { Świadomość } \\
\text { sponsora } \\
\text { Intencja zakupu } \\
\text { produktu } \\
\text { sponsora }\end{array}$ & $\begin{array}{l}\text { Porównanie nowej marki } \\
\text { Orca z markami Nike i } \\
\text { Adidas }\end{array}$ \\
\hline $\begin{array}{l}\text { Garland, } \\
\text { Charbonneau } \\
\text { i } \\
\text { Macpherson } \\
(2008)\end{array}$ & $\begin{array}{l}\text { Dwukrotny pomiar: } \\
\text { I - badanie } \\
\text { kwestionariuszowe } \\
\text { na stadionie, } \mathrm{n}= \\
170 \\
\mathrm{II} \text { - badanie } \\
\text { telefoniczne po } \\
\text { czasie, } \mathrm{n}=129 \\
\text { osób, } \\
\text { rugby }\end{array}$ & $\begin{array}{l}\text { Nowa } \\
\text { Zelandia }\end{array}$ & $\begin{array}{l}\text { Świadomość } \\
\text { sponsora }\end{array}$ & $\begin{array}{l}\text { Porównanie wyników dla } \\
\text { marek krajowych z markami } \\
\text { lokalnymi }\end{array}$ \\
\hline
\end{tabular}




\begin{tabular}{|c|c|c|c|c|}
\hline Autorzy & $\begin{array}{l}\text { Metoda i próba } \\
\text { badawcza }\end{array}$ & Kraj & $\begin{array}{c}\text { Badany efekt w } \\
\text { obszarze } \\
\text { wartości marki }\end{array}$ & $\begin{array}{c}\text { Jak zoperacjonalizowano } \\
\text { zmienną: wcześniejsza } \\
\text { znajomość marki? }\end{array}$ \\
\hline $\begin{array}{l}\text { Breuer i } \\
\text { Rumpf } \\
(2012)\end{array}$ & $\begin{array}{l}\mathrm{N}=85, \\
\text { eksperyment - } \\
\text { eyetracking (26 } \\
\text { krótkich filmów } 4 \\
\text { różnych wydarzeń } \\
\text { sportowych) }\end{array}$ & Niemcy & $\begin{array}{l}\text { Świadomość } \\
\text { sponsora }\end{array}$ & $\begin{array}{l}\text { Pytanie badanych, czy znali } \\
\text { tę markę już wcześniej }\end{array}$ \\
\hline $\begin{array}{l}\text { Walraven } \\
(2013)\end{array}$ & $\begin{array}{l}\text { Dane zbierano w } \\
\text { latach } 2005-2009 \\
\text { (co pół roku), } \\
\text { - panel online } \\
\text { (n = 400-650 osób } \\
\text { na kraj) } \\
\text { - piłka nożna }\end{array}$ & $\begin{array}{l}\text { Francja, } \\
\text { Włochy, } \\
\text { Holandia, } \\
\text { Hiszpania } \\
\text {,Wielka } \\
\text { Brytania }\end{array}$ & $\begin{array}{l}\text { Świadomość } \\
\text { sponsora }\end{array}$ & $\begin{array}{l}\text { Pytanie badanych, czy } \\
\text { kiedykolwiek pili piwo } \\
\text { Heineken? }\end{array}$ \\
\hline $\begin{array}{l}\text { Karpińska- } \\
\text { Krakowiak } \\
(2013)\end{array}$ & $\begin{array}{l}\text { Dwa wydarzenia: } \\
\text { I - Camerimage } \\
(\mathrm{n} 1=176, \mathrm{n} 2= \\
180) \\
\text { II Photo-Festival } \\
(\mathrm{n} 1=258, \mathrm{n} 2= \\
239) \\
\text { Dwie części } \\
\text { badania: } \\
\text { - wypełnianie } \\
\text { ankiety na } \\
\text { festiwalu i po } 6 \\
\text { miesiącach } \\
\text { - sponsoring } \\
\text { wydarzeń } \\
\text { kulturalnych }\end{array}$ & Polska & $\begin{array}{l}\text { Wizerunek marki } \\
\text { sponsora }\end{array}$ & $\begin{array}{l}\text { Respondenci określali, czy } \\
\text { do tej pory byli } \\
\text { użytkownikami marki } \\
\text { sponsora lub jej konkurenta }\end{array}$ \\
\hline $\begin{array}{l}\text { Tsiotsou, } \\
\text { Alexandris i } \\
\text { Cornwell } \\
(2014)\end{array}$ & $\begin{array}{l}\mathrm{N}=280, \\
\text { kwestionariusze } \\
\text { zbierane podczas } \\
\text { meczu, jeden } \\
\text { pomiar, piłka nożna }\end{array}$ & Grecja & $\begin{array}{l}\text { Wizerunek marki } \\
\text { sponsora }\end{array}$ & $\begin{array}{l}\text { Ustosunkowanie się do } \\
\text { twierdzeń: mam wiedzę o } \\
\text { marce sponsora; mam } \\
\text { doświadczenie z marką } \\
\text { sponsora }\end{array}$ \\
\hline
\end{tabular}

Źródło: opracowanie własne.

\subsection{Weześniejsza znajomość marki sponsora wśród uczestników sponsorowanego wydarzenia a zmiany w zakresie wizerunku}

Bazując na dotychczasowych badaniach, efekty, takie jak transfer wizerunku oraz polepszenie stosunku względem sponsora, wydają się bardziej prawdopodobne do osiągnięcia dla mniej znanych marek ${ }^{12}$. Przyczyna tkwi w schematach poznawczych, czyli

\footnotetext{
${ }^{12}$ B.A. Lafferty, R.E. Goldsmith, Cause-brand alliances: Does the cause help the brand or does the brand help the cause?, „Journal of Business Research” 54/8 (2004), s. 423-429.
} 
kognitywnych strukturach posiadanych przez człowieka, reprezentujących wiedzę o całym otaczającym go świecie, w tym również firm i marek. Wiedza konsumencka na temat mało znanych marek charakteryzuje się mniej ustrukturalizowanymi skojarzeniami i słabszymi opiniami niż dla tych znanych ${ }^{13}$. Poznawcze struktury nie są tu tak sztywne, dzięki czemu relatywnie łatwiej je zmienić. I właśnie dlatego w większym stopniu mogą ulegać wpływom skojarzeń związanych z działaniami sponsoringowymi ${ }^{14}$. Napływające nowe informacje dotyczące marki, które wynikają z jej zaangażowania w sponsoring, są łatwo integrowane $\mathrm{z}$ dotychczasowym schematem. Dla marek znanych jest wymaganych natomiast więcej procesów poznawczych w celu przekształcenia poprzednich, relatywnie stabilnych skojarzeń i połączenia ich z nowymi, związanymi ze sponsorowanym wydarzeniem. W tym więc wypadku transfer wizerunku ze sponsorowanego podmiotu będzie słabszy. Potwierdzają to w pewnym stopniu wyniki uzyskane przez KarpińskąKrakowiak $^{15}$, w których zmienna znajomość marki zoperacjonalizowana została jako wcześniejsze z nią doświadczenie. Autorka, prowadząc dwukrotne badania w obszarze sponsoringu kultury, wykorzystała rzeczywiste wydarzenia oraz prawdziwych sponsorów. I choć uzyskane wyniki okazały się zgodne z hipotezę mówiącą, że transfer wizerunku będzie słabszy wśród użytkowników marki sponsora w porównaniu $\mathrm{z}$ grupą nieużytkowników, to różnice były bardzo nieznaczne. Bardzo silną zależność zauważono natomiast między nie-użytkownikami całej kategorii produktów, w której działa sponsor, a siłą transferu wizerunku. Wizerunek firmy sponsorskiej zmienił się bowiem najbardziej u osób, które wcześniej nie miały doświadczenia zarówno z produktami sponsora, jak i $\mathrm{z}$ jego konkurentami.

O istnieniu związku między znajomością firmy, zanim została sponsorem, a osiąganymi efektami w zakresie polepszenia stosunku względem niej świadczą jako jedyne zrealizowane w tym obszarze badania przez Carrillat, Lafferty i Harris. Na podstawie uzyskanych danych od 158 studentów biorących udział w eksperymencie autorzy doszli do wniosku, że zaangażowanie się w działania sponsoringowe firm o mało znanych markach przyczynia się do polepszenia stosunku wobec nich, a taki efekt nie pojawia się, gdy firma ma dobrze znaną markę, jeszcze zanim rozpoczyna sponsoring. Taka konkluzja wymaga jednak przedstawienia metodyki wykorzystanej w badaniu. W eksperymencie oparto się na dwóch firmach: Alltel i Fedex. Ta pierwsza określona została jako nieznana, druga jako znana. Z firmy Alltel korzystało wcześniej 19\% badanych, z firmy Fedex 36,6\%. Gdy respondenci oceniali na skali 1-7 znajomość obu firm, różnica, choć okazała się istotna, nie była wielka. Podmiot określony jako nieznany uzyskał średnią 3.0, znany zaś - średnią równą 3.9. Porównując wyniki dla tak określonych firm, stosunek wobec tej znanej był taki sam wśród osób wystawionych na ekspozycję informacji o sponsoringu (grupa eksperymentalna), jak wśród osób niewystawionych (grupa kontrolna). Stosunek wobec firmy nieznanej był natomiast

\footnotetext{
${ }^{13}$ B.L. Simonin, J.A. Ruth, Is a company known by the company it keeps? Assessing the spillover effects of brand alliances on consumer brand attitudes, „Journal of Marketing Research” 35/1 (1998), s. 30-42; G.S. Low, C.W.J. Lamb, The measurement and dimensionality of brand associations, „Journal of Product and Brand Management" 9/6 (2000), s. 350-368.

${ }^{14}$ D.H. Dean, Associating the corporation with a charitable event through sponsorship: Measuring the effects on corporate community relations, ,Journal of Advertising” 31/4 (2002), s. 77-87.

${ }^{15}$ M. Karpińska-Krakowiak, The Impact of Consumer Knowledge on Brand Image Transfer in Cultural Event Sponsorship, „Polish Sociological Review” 2/182 (2013), s. 185-207.
} 
istotnie wyższy wśród grupy wystawionej na sponsoring w stosunku do grupy kontrolnej. Zatem tylko w wypadku mało znanej firmy jej zaangażowanie w sponsoring przyczyniło się do polepszenia stosunku wobec niej wśród fanów sponsorowanego podmiotu. Warto tu jednak dodać, że mimo braku wpływu informacji o sponsoringu na stosunek wobec firmy znanej i tak cieszyła się ona pozytywniejszym nastawieniem wśród osób badanych w porównaniu z firmą nieznaną.

\subsection{Znajomość firmy, zanim została sponsorem, a świadomość jej sponsoringu}

Choć, jak wynika z wcześniej przedstawionych badań, angażowanie się znanej firmy w działania sponsoringowe nie służy zmianie jej wizerunku i polepszeniu nastawienia wobec niej, pomaga zaś osiągać efekty w innym obszarze. Dotychczasowe badania pokazują, że znane marki mają większą szansę na bycie zidentyfikowanym jako sponsor danego wydarzenia. Ogólna znajomość firmy pomaga uczestnikom wydarzenia w udzieleniu odpowiedzi, gdy proszeni są o wymienienie firm je sponsorujących. Zależność między wcześniejszą znajomością firmy $X$ a świadomością tej firmy jako sponsorującej podmiot $\mathrm{Y}$ była przedmiotem badawczym aż $\mathrm{w}$ ośmiu wymienionych $\mathrm{w}$ tabeli artykułach. Tylko jednak w dwóch wpływ znajomości firmy (w preteście) na świadomość sponsora (w postteście) sprawdzano w rzeczywistych warunkach, korzystając z metodyki opartej na powtarzanych pomiarach PRE i POST.

W pierwszym badaniu Grohs, Wagner i Vseteck ${ }^{16}$, dokonując dwukrotnego pomiaru na tych samych 132 uczestnikach Mistrzostw Świata w narciarstwie alpejskim, potwierdzili wspomnianą hipotezę wyłącznie dla jednej $\mathrm{z}$ dwóch badanych marek. W drugim Walraven ${ }^{17}$ znajomość marki zoperacjonalizował jako wcześniejsze z nią doświadczenie. Opierając się na wynikach z pięcioletnich pomiarów prowadzonych co pół roku w pięciu europejskich krajach, których przedmiotem były rozgrywki piłkarskie w pucharze UEFA i ich sponsor tytularny - Heineken, doszedł do wniosku, że wcześniejszy zakup piwa wspomnianej marki pozytywnie wpływa na jej świadomość jako sponsora wydarzenia.

Warto tu jeszcze wspomnieć o dwóch badaniach z Nowej Zelandii. W pierwszym Garland, Charbonneau i Macpherson ${ }^{18}$, realizując pomiary podczas dwóch meczów rugby uzyskali wyniki potwierdzające, że firmy posiadające silne marki są łatwiej przywoływane jako sponsorzy. Do takich wniosków doszli po porównaniu wskaźnika świadomości sponsorów dla znanych firm (Lion Red oraz Manawatu Toyota) ze wskaźnikiem świadomości sponsorów dla przedsiębiorstw lokalnych (Radio XS). Omawianą relację przedstawia również badanie Hoek, Gendall i Wood ${ }^{19}$ bazujące na Olimpiadzie w Atenach. Porównywano efekty nowego producenta strojów drużyny olimpijskiej Nowej Zelandii - firmy Orca, z efektami osiąganymi przez takie znane marki jak Nike czy Adidas. Odpowiednio 38\% i 37\% badanych identyfikowało firmy Adidas i Nike jako oficjalnych sponsorów Nowej Zelandii, a tylko $24 \%$ było świadomych sponsorowania przez firmę Orca. Wyniki obu tych badań sugerują, że ogólna znajomość

\footnotetext{
${ }^{16}$ R. Grohs, U. Wagner, S. Vsetecka, Assessing the Effectiveness of Sport Sponsorships - an Empirical Examination, „Schmalenbach Business Review” 56/2 (2004), s. 119-138.

${ }^{17}$ M. Walraven, op. cit.

${ }^{18}$ R. Garland, J. Charbonneau, T. Macpherson, Measuring sport sponsorship effectiveness: links to existing behavior, „Innovative Marketing” 4/1 (2008), s. 46-51.

${ }^{19}$ J. Hoek, P. Gendall, Z. Wood, Knowledge, Brand Use And Sponsorship Attribution, „Conference: Sports, Arts and Heritage Marketing" 2005, s. 22-28.
} 
marki wpływa na zdolność przywołania jej w sytuacji rozważania nazw sponsorów. W obu artykułach brakuje jednak informacji dotyczących wielkości pakietów sponsorskich poszczególnych firm oraz podejmowanych przez nie dodatkowych działań marketingowych.

W pozostałych badaniach w tym obszarze autorzy, wykorzystując metodę eksperymentu, potwierdzili, że czołowe marki są bardziej dostępne w pamięci, dlatego $\mathrm{Z}$ większym prawdopodobieństwem mogą być wymienione jako sponsor wydarzenia ${ }^{20}$.

\subsection{Znajomość firmy, zanim została sponsorem, a wielkość zmian w zakresie intencji zakupu jej produktów}

Rola dotychczasowej wiedzy konsumenckiej na temat firmy rozpatrywana była również w ocenie efektów sponsoringowych określanych za pomocą wskaźnika, jakim jest wzrost intencji zakupu. Która firma może zatem liczyć na większy przyrost chęci kupna jej produktów - ta, która wśród uczestników sponsorowanego wydarzenia była znana, zanim zaangażowała się w sponsoring, czy ta nieznana? Na tak postawione pytanie starano się odpowiedzieć tylko w jednym badaniu. Uzyskane wyniki z wcześniej już przedstawionego eksperymentu przeprowadzonego przez Carrillat, Lafferty i Harris pozwalają twierdzić, że w omawianym aspekcie bardziej zyskują mało znane marki. Po porównaniu wyników dotyczących intencji zakupu produktów mało znanych marek z dobrze znanymi (uzyskanych w dwóch grupach: kontrolnej i eksperymentalnej) okazało się, że wzrost intencji odnotowano tylko dla tych pierwszych. W sytuacji sponsorowania przez dobrze znaną markę intencja jej zakupu nie zmieniła się. Omawiany efekt został zatem zauważony tylko wśród osób, które wcześniej słabo znały markę. Uzyskany wynik może być nieco zaskakujący i trudny do przyjęcia. Przez jego pryzmat bowiem trudno wytłumaczyć, dlaczego znane marki, dążąc do zwiększenia sprzedaży swoich produktów, angażują się w sponsoring. Ryzykowne jest jednak wyciąganie takich wniosków na podstawie wyłącznie jednego badania w tym obszarze. Niestety obecnie tylko to jest dostępne.

\section{PODSUMOWANIE}

Pierwszym, szczególnie ważnym wnioskiem wyłaniającym się z przeprowadzonego przeglądu literatury jest bardzo mała liczba zrealizowanych do tej pory badań, w których podjęte zostały rzeczywiste próby określenia wpływu zmiennej niezależnej, czyli znajomości przez fanów firmy rozpoczynającej sponsorowanie danego wydarzenia, na osiągane przez tę firmę efekty w obszarze marketingowej wartości swojej marki. Drugi, równie istotny wniosek dotyczy stosowanych metodyk badawczych, które niestety ograniczają wartość predykcyjną uzyskanych wyników. Dostępne nieliczne badania w znacznej mierze oparte są na metodzie eksperymentu przeprowadzanego z użyciem fikcyjnych aliansów sponsoringowych. Inną grupą badań są te, co prawda

\footnotetext{
${ }^{20}$ C. Breuer, C. Rumpf, The Viewer's Reception and Processing of Sponsorship Information in Sport Telecasts, „Journal of Sport Management”, 26 (2012), s. 521-531; G.V. Johar, M.T. Pham, Relatedness, Prominence, and Constructive Sponsor Identification, „Journal of Marketing Research” 1999/36, s. 299-312; M.T. Pham, G.V. Johar, Market prominence biases in sponsor identification: processes and consequentiality, „Psychology \& Marketing" 18/2 (2001), s. 123-143; K. Wakefield, K. Becker-Olsen, T.B. Cornwell, I Spy a Sponsor: The Effects of Sponsorship Level, Prominence, Relatedness and Cueing on Recall Accuracy, „European Advances in Consumer Research" 36/4 (2006), s. 61-74
} 
przeprowadzone na rzeczywistych wydarzeniach i ich uczestnikach, jednak ograniczenie w obszarze wnioskowania wiąże się ze skupianiem się na długoletnich już sponsorach lub wynika $\mathrm{z}$ oparcia konkluzji tylko na jednokrotnym pomiarze. Uniemożliwia to zaobserwowanie zmian. Ponadto zróżnicowane podejście do operacjonalizacji omawianej zmiennej niezależnej utrudnia porównywanie dostępnych wyników.

Wymienione ograniczenia z pewnością nie pozwalają na wnioski, o których można by mówić z pełnym przekonaniem. Niewątpliwie jednak dotychczasowy dorobek stanowi silną przesłankę, by sądzić, że rola wcześniejszej znajomości marki sponsora w osiąganiu różnych efektów w obszarze wartości marki jest istotna. Wyniki przedstawionych w tabeli badań sugerują, że określenie przed podjęciem działań sponsorskich poziomu znajomości firmy wśród widzów sponsorowanego wydarzenia może pomóc jej w oszacowaniu skali korzyści płynących z zaangażowania się w tę formę promocji. Inwestycja sponsoringowa może być bowiem mniej dostosowanym narzędziem dla tych znanych firm, które za cel stawiają sobie polepszenie stosunku wobec własnej marki oraz zmianę swojego wizerunku. $\mathrm{Na}$ te rezultaty $\mathrm{z}$ większym prawdopodobieństwem mogą liczyć firmy angażujące się w sponsoring, które do tej pory nie były zbyt znane wśród widzów sponsorowanego podmiotu. Odwrotnie przedstawia się natomiast sytuacja, kiedy celem firmy jest zyskanie świadomości bycia sponsorem. Silna marka zwiększa bowiem szansę na bycie zidentyfikowanym jako sponsor danego wydarzenia. Jeśli firma inwestuje w sponsoring, oczekując w zamian wzrostu intencji zakupów swoich produktów, jedno eksperymentalne badanie w tym zakresie pokazuje, że swoje oczekiwania zaspokoją tylko managerowie $\mathrm{z}$ mało znanych firm.

\section{LITERATURA}

[1] Aaker D.A., Building strong brands: Capitalizing on the value of brand name, The Free Press, New York 1996

[2] Alba J.W., Hutchinson J.W., Dimensions of consumer expertise, „Journal of Consumer Research"13/4 (1987).

[3] Breuer C., Rumpf C., The Viewer's Reception and Processing of Sponsorship Information in Sport Telecasts, „Journal of Sport Management” 2012/26.

[4] Carrilat F.A., Harris E.G., Lafferty B.A., Investigating sponsorships effectiveness: Do less familiar brands have an advantage over more familiar brands in single and multiple sponsorship arrangements?, „Journal of Brand Management” 13/1 (2005).

[5] Cornwell T.B., Maignan I., An international review of sponsorship research, „Journal of Advertising" 27/1 (1998).

[6] Dean D.H., Associating the corporation with a charitable event through sponsorship: Measuring the effects on corporate community relations, „Journal of Advertising” 31/4 (2002).

[7] Garland R., Charbonneau J., Macpherson T., Measuring sport sponsorship effectiveness: links to existing behavior, „Innovative Marketing” 4/1 (2008).

[8] Grohs R., Wagner U., Vsetecka S., Assessing the Effectiveness of Sport Sponsorships - an Empirical Examination, „Schmalenbach Business Review” 56/2 (2004).

[9] Gwinner K.P., Eaton J., Building Brand Image Through Event Sponsorship: The Role of Image Transfer, ,Journal of Advertising” 28/4 (1999).

[10] Gwinner K., Swanson R.S., A model of fan identification: antecedents and sponsorship outcomes, ,Journal of Services Marketing” 17/3 (2003).

[11] Hoek J., Gendall P., Wood Z., Knowledge, Brand Use And Sponsorship Attribution, „Conference: Sports, Arts and Heritage Marketing” 2005. 
[12] IEG, Sponsorship Outlook: Spending increase is double-edged sword, IEG Sponsorship Report 2013.

[13] IEG, Sponsorship spending report 2014.

[14] IEG, Sponsorship spending report 2015.

[15] Johar G.V., Pham M.T., Relatedness, Prominence, and Constructive Sponsor Identification, „Journal of Marketing Research” 1999/36.

[16] Karpińska- Krakowiak M.., The Impact of Consumer Knowledge on Brand Image Transfer in Cultural Event Sponsorship, „Polish Sociological Review” 2/182 (2013).

[17] Keller K.L., Conceptualizing, Measuring and Managing Customer Based Brand Equity, „Journal of Marketing” 1993/57.

[18] Lafferty B.A., Goldsmith R.E., Cause-brand alliances: Does the cause help the brand or does the brand help the cause?, ,Journal of Business Research” 54/8 (2004).

[19] Low G.S., Lamb C.W.J., The measurement and dimensionality of brand associations, „Journal of Product and Brand Management" 9/6 (2000).

[20] Meenaghan T., The role of sponsorship in the marketing communication mix, ,International Journal of Advertising" 10/1 (1991).

[21] Meenaghan T., O'Sullivan P., Metrics in Sponsorship Research - Is Credibility an Issue?, „Psychology and Marketing” 30/5 (2013).

[22] Pham M.T., Johar G.V., Market prominence biases in sponsor identification: processes and consequentiality, „Psychology \& Marketing” 18/2 (2001).

[23] Simonin B.L., Ruth J.A., Is a company known by the company it keeps? Assessing the spillover effects of brand alliances on consumer brand attitudes, „Journal of Marketing Research" 35/1 (1998).

[24] Speed R., Thompson P., Determinants of sport sponsorship response, „Journal of the Academy of Marketing Science" 28/2 (2000).

[25] Sponsoring - podstawowy instrument marketingu sportowego, Deloitte i Krajowa Izba Sportu, Warszawa 2012.

[26] SRI, World-Wide Sponsorship Market Values, Sponsorship Research International, London 2001.

[27] Tsiotsou R.H., Alexandris K., Cornwell T.B., Using evaluative conditioning to explain corporate co-branding in the context of sport sponsorship, „International Journal of Advertising" 33/2 (2014).

[28] Wakefield K., Becker-Olsen K., Cornwell T.B., I Spy a Sponsor: The Effects of Sponsorship Level, Prominence, Relatedness and Cueing on Recall Accuracy, „European Advances in Consumer Research" 36/4 (2006).

[29] Walliser B., An international review of sponsorship research: An extension and update, „International Journal of Advertising” 2003/22.

[30] Walraven M., Sports Sponsorship Effectiveness. Investigating awareness, sponsor equity and efficiency, dysertacja doktorska, 2013.

\section{PRIOR BRAND FAMILIARITY AS A DETERMINANT OF SPONSORSHIP EFFECTS WITHIN BRAND EQUITY}

Companies, which are engaged in sponsorship, decide for that kind of promotion, expecting specific profits in return. The spectrum of possible achievements is very wide. The number of variables, which have direct or indirect impact on the level of results, is sizeable as well. In the article the author is trying to define, what is the relation between prior familiarity 
(among fans) of the sponsor brand and outcomes reached by the sponsor within brand equity. So there is a question, whether the companies, that fans aren't familiar with, might reach the same brand equity effects, as the known ones?

Brand equity and changes within it, that are results of sponsorship investment are analyzed in four dimensions like brand awareness, brand image, attitude toward brand and purchase intention. Academic achievements in this framework is still very little. The main input of this paper is to sum up the existing literature, which means knowledge presentation from the previous researches. It is to help to understand this relation and indicate areas required for further researches as well. The article ends with practical recommendiations for present and future sponsors. The understanding offered in this paper might be crucial for brand managers in estimating effects of sponsorship decisions.

Keywords: sponsorship, sponsorship effects, brand familiarity, brand equity, determinants of sponsorship outcomes

\section{DOI: 10.7862/rz.2016.mmr.18}

Tekst złożono w redakcji: kwiecień 2016

Przyjęto do druku: wrzesień 2016 